\section{Jurnal Hukum Volkgeist \\ Volume 5 Issue 2, 2021 \\ P-ISSN : 2528-360X, E-ISSN : 2621-6159}

HuKuM

Mimbar Pendidikan Hukum Nasional

\title{
Juridical Review of The Application of Digital Mapping (Plotting) of Land Ownership Rights in The Prevention of Multiple Certificates
}

\author{
Mashendra $^{1 *}$, Deddy Mursanto $^{1}$
}

\begin{abstract}
The implementation of land registration aims to create an accurate information center regarding land ownership. To ensure that land registration administration runs effectively, the Computerization of Land Activities (KKP) policy is implemented gradually and thoroughly. Even so, the application of a computerized system that is so sophisticated, still finds overlapping ownership ofland titles. Overlapping the certificate will result in legal uncertainty for the certificate holder, because the main purpose listed is to get the certificate as valid evidence.. Sampling in this study was carried out purposively with a nonrandom sampling technique that focused only on land that had multiple certificates. The data analysis pattern in this study is based on qualitative methods. The findings of this study are thatThe implementation of Computerization of Land Activities (KKP) at BPN City of Baubau in preventing the occurrence of double certificates is carried out with all processes from the beginning of land registration to issuance of certificates and stored digitally. The factors that result in the occurrence of a double certificate can be seen from 2 (two) things, namely first, when viewed from the factor of the Community. Second, if it is seen from the human resource factor of the Land Officedue to carelessness and carelessness of the land officers.
\end{abstract}

Keywords: Land Ownership, Double Certificate, KKP

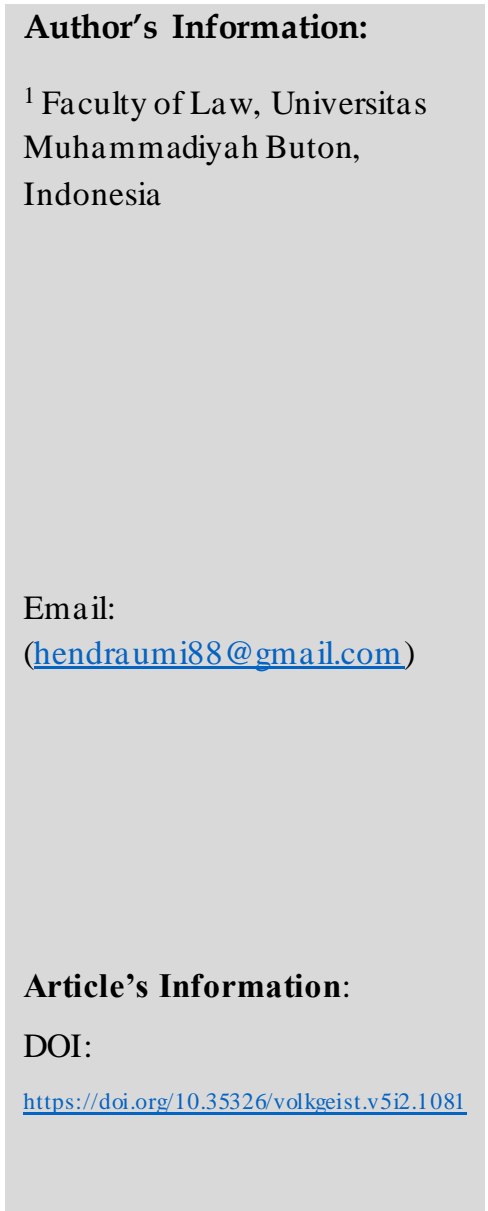

\section{Introduction}

Land as part of the surface of the earth, has a very important meaning in the life of a nation, which must be guarded and utilized properly with legal rules that must be implemented seriously and orderly because land reflects the dignity of an individual, group and even the sovereignty of an individual. nation. In the history of the Indonesian state, land has become one of the main objects in legal development, especially because the existence of land directly touches the basic needs of all levels of society to live and carry out activities within the framework of state sovereignty (Sutedi, 2008).

A land problem is very actual for humans where alone, is said to be mainly in development. Based on observations on the implementation of supervisory duties, providing to us that the problem soil is an important factor that influence on the course of development (Salam, 2017). 
Before the birth of colonial agrarian law, in Indonesia customary land law and self-governing land law were applied. Customary land law is original law that has its own legitimacy where the right to land owned is a private right in which there is an element of togetherness to support social functions (Razak, Patittingi, \& Maskun, 2020). Meanwhile, the self-governing land law is the law on land given to the part of the region recognized by the colonial government and includes various forms of administration, such as sultanates, kingdoms and duchies. Self-governing status means that the area is led by a native who has the right to manage administrative, legal and internal cultural affairs (Sumaya, 2018).

In the New Order era the need for laws regulating agrarian issues to guarantee and provide legal certainty over land ownership was an urgent one so that on September 24, 1960, Law Number 5 was enacted concerning the Basic Basic Regulations for Agrarian Affairs which abbreviated as UUPA. This law was created with considerations and a long process, where the law adheres to legal unification based on customary law (Negara Kesatuan Republik Indonesia, 1960).

To ensure legal certainty and rights to land, regulates and requires Indonesian people to register their land (Santoso, 2019). Apart from ensuring certainty of rights, the purpose and objective of the implementation of land registration is to create an accurate information center on land parcels. With this information base, the relevant parties, including the government, can easily obtain accurate data in regulating and deciding the guarantee of rights regarding the disputed land parcels. As the end of the land registration, the land owner is entitled to obtain a land certificate issued by the National Land Agency as a form of legal guarantee and protection for the land parcels they own. The implementation of land registration is a form of orderly administration in the land sector (Parmahan Sibuea, 2011).

Many steps have been taken by the government to make land registration administration services run more efficiently and effectively. One of them is by issuing a policy on the Computerization of Land Activities (KKP). The application of the KKP system is so sophisticated, we still find overlapping ownership of the land. With overlapping certificates, it will result in legal uncertainty for the certificate holder, because the main purpose is listed to get the certificate as valid evidence.

This can occur due to several factors including, due to human error committed by the land office officials. The inaccuracy and inaccuracy carried out by the land officers in checking and researching the parcels of land the community requested. In addition, the limitation of the land data being requested can be a factor in the existence of multiple certificates, usually the land data is lost or scattered so that the land data is no longer found. This could also occur due to the lack of data on land that is neither registered nor registered with the National Land Agency.

In addition, overlapping certificates can also occur because the community itself, usually there are still many people who do not fully control the boundaries of their land, the dishonesty factor of the certificate owner who has sold their land several times, and it is also common for the community to deliberately or unintentionally show it. wrong land boundaries with a certain max. Of course this is one of the causes for the emergence of land disputes in society.

It is hoped that the computerized service pattern can reduce problems related to land. This is supported by the Circular of the Head of the Indonesian National Land Agency Number 5 / SE-100 / I / 2015 concerning the Use of Computerized Applications 
for Land Activities to carry out all types of land services as well as dispute and conflict resolution at the Office of the Ministry of Agrarian Affairs and Spatial Planning / National Land Agency, Office Territories of the National Land Agency and Regency / City Land Offices.

\section{Methodology}

This research uses an empirical legal approach to answer the formulated problems because the scope of this research is only to carry out legal studies in practice which are always framed by legal doctrines. The juridical approach is carried out by using legal provisions that apply in Indonesia. In addition, this study applies a normative approach by examining library materials by studying and examining theories, concepts and regulations related to problems.

The population of this research is all people who take care of land certificates and employees of the land office of Baubau City, Southeast Sulawesi Province. Sampling was carried out purposively with focus only on land which has a overlap certificate (double certificate). The sampling technique is purpose sampling. The data analysis pattern in this study was based on qualitative methods, namely through qualitative interpretation of the collected data, both primary and secondary data. This qualitative analysis which is descriptive and analytical in its analysis activities is based on normative juridical analysis, methods of data collection by means of observation, interviews, and documentation.

\section{Result and Discussion}

\subsection{Implementation of Computerization of Land Activities (KKP) in Preventing Double Certificates (Overlapping) at BPN City of Baubau}

The National Land Agency has made several efforts to prevent the occurrence of double certificates, one of which is by procuring land registration maps, which have begun to be carried out in stages which are carried out by measuring from village to village. Given the implementation of land registration maps takes a long time. This Village by Village measurement is contained in the provisions of Regulation Number 10 of 1961 concerning land registration. In order to prevent this Double Certificate, the National Land Agency has programmed the procurement of a digital Land Registration Map.

Improving the quality of services in the land office and to carry out the functions and duties of the Ministry of Agrarian Affairs and Spatial Planning / National Land Agency of Baubau City, it has used technology and communication-based system applications, namely computerization of land activities. The Information and Communication Technology-based application is provided to support the quality of service in the context of mapping and regulation as well as solving problems related to land. The use of computerized applications for land activities at the Baubau City Land Agency aims to:

1. Improve the quality of services at the BPN city of Baubau;

2. Make it easier for the community to access land services;

3. Coordinating all services of all Sub-Section fields in the Land Office of Baubau City; 
4. Facilitate management in terms of land registration and settlement of land conflicts;

5. Helping the tasks and functions of the BPN City of Baubau become much easier;

6. Modernizing existing services at BPN Kota Baubau.

The KKP application is available and can be used to carry out activities related to land and the resolution of problems and conflicts at the Land Office of Baubau City.

Table. 3 Number of Land Rights (Source: BPN Baubau)

\begin{tabular}{cccc}
\hline NO & LAND RIGHTS & YEAR & TOTAL \\
\hline \multirow{3}{*}{1} & \multirow{3}{*}{ Proprietary Right } & 2015 & 1693 \\
\cline { 3 - 3 } & & 2016 & 3002 \\
\cline { 3 - 3 } & & 2017 & 6012 \\
\cline { 2 - 3 } & 2018 & 3955 \\
\cline { 2 - 3 } & 2019 & 9806 \\
\hline
\end{tabular}

Based on data from the Land Office of Baubau City, the land ownership rights from 2015-2019 amounted to 24,468. In 2015 there were 1,693, in 2016 there were 3,002, in 2017 they were 6,012, in 2018 they were 3,955 and in 2019 they were 9,806. The land agency of the City of Baubau implements computerized land activities (KKP) to prevent double certificates, that is, all processes from the initial land registration to the issuance of the certificate are digitized / computerized. Its implementation includes:

a. PTSL data (complete systematic land registration) are kept / stored in electronic / digital form.

b. management of land rights through computerized / digital.

c. Land measurement data (land area, land boundaries) is stored in electronic / digital form

d. Land registration mapping is done digitally (ploting)

According to the Head of the Sub-Section for Basic and Thematic Measurement and Mapping (La Ode Safrin), plotting is the process of online / digital land remapping. The plotting process is carried out by means of a BPN officer with a certified person together to the land location, then the location of the land coordinates, then take the location of the land coordinates into the KKP, then the image of the certificate is scanned (digitized) including the land NIB. Then the land is mapped according to the location coordinates earlier. Land that has been certified but has not been plotted must be reported to BPN for plotting. (interview, Tuesday 18 February 2020)

e. Data / digital land certificate creation (certificate data is stored in electronic / digital form).

According to Dirham., SH, (Head of Sub-section on land rights and community land empowerment), that one of the obstacles to the implementation of the KKP is bad network and blackout. However, I think the implementation of the KKP is quite effective. It's just that there are still obstacles as previously described. (Interview, Monday, February 17, 2020).

Implementing and using computerized application of land activities carried out consistently and developing them in accordance with the Decree of the Head of BPN RI No. 277 of 2012 concerning sapta Land order, indicators of land administration orderly 
implementation. The use of the KKP application can improve the quality of services in the land sector and can minimize errors that usually occur when done manually.

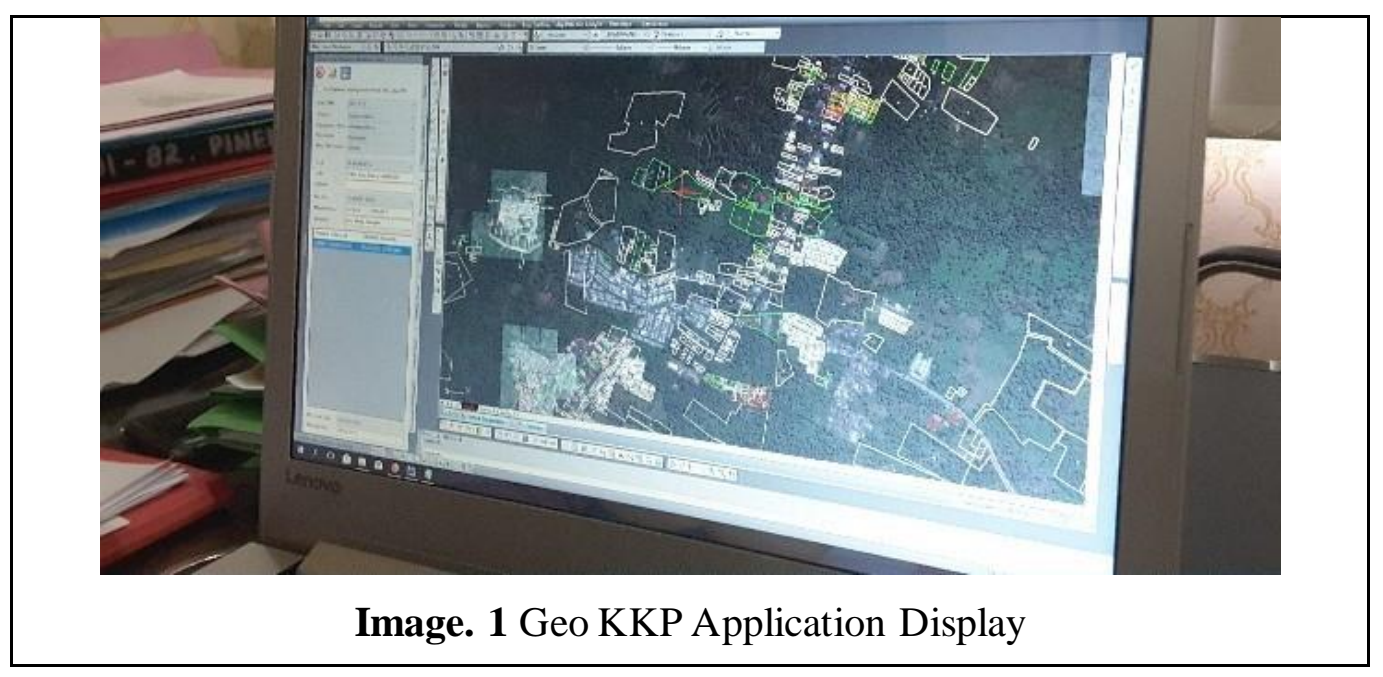

With a computerized service pattern as it is today, of course it will increase higher accuracy of the data to be processed, for example in terms of matching physical data and juridical data, with the KKP application system checking physical data and juridical data can be done with more time efficiency. fast and accurate when compared to checking manually. In addition, services using the KKP application make it easier for the public to access land services, and provide information transparency to the general public. In using the KKP application in terms of preventing overlapping certificates, this application functions to enter any data from the initial land registration until the certificate issuance is carried out and stored in electronic form which is then entered in the KKP application.

This application also presents land plots that have been mapped in the KKP application and land plots that have not been mapped in the KKP application. The land registration data is then entered into the KKP Geo server, which is a system derived from the KKP application and then checked for the authenticity of the data. The function of this KKP Geo is to present an overview of land parcels that have been mapped in the KKP application and the unmapped fields in the KKP application. Of course, with the help of Geo, KKP can parse the problems that arise related to overlapping land parcels status, because one of the factors affecting the overlapping of certificates is due to limited data and information related to land parcels that have been certified and land parcels that have been certified. not yet certified.

With the help of Geo KKP, problems that often occur in registration, such as double certificates for the status of land parcels, can be avoided. Because this application can provide a comprehensive overview of land parcels in an area, both certified and uncertified. The use of the KKP application is of course very useful for resolving and reducing disputes that occur due to overlapping ownership certificates over the status of land parcels. This application works by presenting information related to land as a whole with a high degree of accuracy, faster time efficiency so that it does not take a long time and saves costs. With the KKP application, the community does not need to worry anymore if the original ownership certificate is lost, because with the use of this KKP application there is a digital certificate program which is expected to help and facilitate the community in accessing data on their land ownership, namely by entering the password or password for the land to be applied by the KKP. 
With the opening of the circular letter of the Head of the National Land Agency of the Republic of Indonesia Number 5 / SE-100 / I / 2015 concerning the use of computerized application of land activities in the National Land Agency of Baubau City, it has implemented computerization of land activities in relation to preventing the occurrence of double certificates by means of all data from the initial registration. land until the certificate is issued and stored using computerized. Furthermore, all data related to land registration are entered into the KKP Geo serer, which is a system derived from the KKP application to check the authenticity of the land data. This KKP Geo system also presents the entire land parcels that have been certified and those that are not yet certified, which are then entered into the KKP application. With the computerized application of Land Activities and its derivative application, namely Geo $\mathrm{KKP}$, it is hoped that it can reduce the problems and conflicts that arise as a result of double certificates of the status of land parcels that overlap with one another, either in whole or in part.

However, in reality, with computerized services such as the current BPN B aubau, certificates overlap still occur. Here are 3 findings of a double certificate at BPN Baubau from 2015-2019 as follows:

1. SHM NO. 00640 / Kel Bukit Wolio Indah Year 2014 on behalf of Moane In Tinder. SHM NO. 01992 / Kel Bukit Wolio Indah Year 2014 on behalf of Zaeru

2. SHM NO. 00426 / Kel Sulaa 2006 on behalf of Lutfi Hasan, SHM NO. 00646 /Kel Sulaa 2007 on behalf of Hasan Pou, SHM NO. 00419 / Kel Sulaa 2006 on behalf of LD. MZ Sakti Qadratullah, SHM NO. 00644 / Kel Sulaa 2007 on behalf of Anas Maisu, SHM NO. 00418 / Kel Sulaa 2006 on behalf of WD. Masfida, SHM NO. 00414 / Kel Sulaa 2006 on behalf of Mohammad Kamil. In Tinder, SHM NO. 3102 / Kel Sulaa Year 2017 on behalf of La Runa, SHM NO. 3092 / Kel Sulaa Year 2017 on behalf of La Munara, SHM NO. 3129 / Kel Sulaa Year 2017 on behalf of Zanudin, SHM NO. 3142 / Kel Sulaa Year 2017 on behalf of La Ingke, SHM NO. 3081 / Ex Sulaa 2017 on behalf of La Sindi

3. SHM NO. 100 / Kel Tarafu 1996 on behalf of La Hiad. In Tinder, SHM NO. 00732 / Kel Tarafu Tahun 2017 on behalf of Aminu.

Of the three findings, all of these double certificates occurred because there were still many land certificates that were not registered in the KKP application.

\subsection{Factors that influence the occurrence of double certificates (overlapping) in BPN Kota Baubau}

With the existence of multiple certificates that overlap with one another on the same land parcel object, the problem that will arise is that it will result in legal uncertainty for the certificate holder (Rizki, 2020). The National Land Agency explained that, overlapping certificates usually occurred on parcels of land that were still empty and no buildings had yet been built on the land. The factors that cause a double certificate, can be seen from 2 factors, namely:

\subsubsection{Community factor}

When viewed from the aspect of society, many things cause the double certificate, based on the results of an interview with Dwi Almuswahir Zuliadi as a legal analyst for BPN City of Baubau said that:

"One of the factors in the occurrence of a double certificate is because the community itself does not directly control the land, the person who manages or 
manages the land is not committed, where he will only take care of it if the land owner is in the location, at the time of measuring or researching the field, the applicant deliberately or accidentally showing the location of the land and the wrong boundaries, the existence of a letter of proof or acknowledgment of the right after the date is proven to contain untruth, falsity or is no longer valid, for the area concerned the land registration map is not yet available and also the case of issuing more than one certificate of a parcel of land can also occur on inherited land. The background of this case is the dispute over inheritance property, namely by the owner before his death had been sold to another party (unknown to his children) and a certificate was issued on behalf of the buyer, and then the heirs certified the same land, resulting in a double certificate. because the previous certificate had not been mapped online in the KKP application" (interview, Tuesday, February $18,2020)$.

According to the Head of the Sub-Section of Basic and Thematic Measurement and Mapping (La Ode Safrin), one of the factors of overlapping is seen from the aspect of society, namely:

"It could be that the certificate owner does not understand the boundaries of the land or usually the person who has the certificate has sold the land several times so that the person who buys the land becomes the victim (dishonesty of the land owner)". (interview, Tuesday, 18 February 2020)

\subsubsection{The Land Office Human Resource Factor.}

The occurrence of multiple certificates can also be caused by human resource factors (Chandra, 2020). As happened in the Land Office of the City of Baubau, the cause is that sometimes the land officers are not thorough and inaccurate in checking both physical data and juridical data on the land area that is being applied for certification. So that data errors occur when making land certificates and cause overlapping certificates on the same land parcel object, either in whole or only part of the land that is being applied for.

Based on the results of an interview with Mr. Muhammad Zakaria as the Head of the Land Infrastructure Section who said that:

"Another factor that could cause overlapping certificates could be that sometimes due to the mistakes of the BPN officers themselves, the BPN officers' lack of thoroughness could be, the BPN officers thought the land parcels registered were not yet certified but it was only recently discovered that the land was overlapping" . (interview, Tuesday, 18 February 2020)

This is in line with the statement from Mr. La Ode Safrin as Head of the SubSection of Basic and Thematic Measurement and Mapping who said that:

"It is true that one of the factors in the overlapping of certificates could be the human error of the Land Office officers. This can happen because usually there is missing data, it could also be that the data on the land parcels is scattered. What is clear is that this is not an intentional element. BPN officers usually forget to save where the land data is or can also be scattered or not found, usually due to moving rooms or offices so that some data is scattered or cannot be obtained again ". (interview, Tuesday, 18 February 2020)

However, apart from the factors described above, there are also other factors that have become one of the main factors causing overlapping certificates or double 
certificates since the KKP came into force, namely that there are still many lands that have been certified but have not registered in the KKP application(Pranoto, 2020).

Based on the results of an interview with Mr. La Ode Safrin as the Head of the Sub-Section for basic and thematic measurement and mapping, said that:

"Overlapping certificates can also occur because the land has been certified but has not been plotted in the KKP application. To date, the Land Office of Baub au City has issued 52,552 ownership certificates. Of the total number of certificates, 27631 ownership certificates have been plotted on the KKP application and 24,921 ownership certificates have not been plotted on the KKP application. (in terview, Tuesday, 18 February 2020)

Based on the explanation above, there are still many land certificates that have not been plotted or registered in the KKP application, of course this can be one of the factors causing overlapping certificates or multiple certificates. This is in line with what was conveyed by Mr. La Ode Maniana as Head of the Land Issues Management and Control Section, saying that one of the main factors that led to the occurrence of double certificates, namely:

"There is already a KKP, but not all of it is in the KKP. The KKP in relation to the prevention of double certificates has not been comprehensive in all certified land parcels registered in the KKP application. So that there are land measurements and land certificates which were not problematic in the past but since the KKP came into effect only problems have arisen, because there are more people who have applied for status in the previously certified land parcel. BPN does not see whether this land is certified or not so there will be a new process to be certified, this is because the land parcels that have been certified have not been registered or have not been mapped in the KKP application. So that BPN continues to process the land as the first application, this first application is a land registration that has never been measured or registered before. What should have been no longer a first-time application because the land parcel has been certified, it should have been a request for separation, an application for merger or an application for restriction of boundaries. (in terview, Tuesd ay, 18 February 2020).

According to the Head of the Sub-Section of Basic and Thematic Measurement and Mapping (La Ode Safrin), one of the factors of overlapping is seen from the aspect of the land office, namely:

"There are still a lot of land that has been certified but not plotted, hu man error from BPN officers (accidental factor), for example: certificate data was scattered when moving offices, lack of thoroughness from BPN officers". (interview, Tuesday, 18 February 2020)

According to Laode Maniana (head of the problem complaint section), the factors that occurred were overlapping, namely: "there is already a KKP but everything has not been in the KKP, is not comprehensive, and lacks control over land officers, lack of thoroughness in land officials." (interview, Tuesday, 18 February 2020)

\section{Conclusion}

Implementation of Computerization of Land Activities (KKP) at BPN City of Baubau in preventing the occurrence of double certificates is carried out with all processes from the beginning of land registration to issuance of certificates carried out and stored digitally / computer. Spatial data (registration maps) and textual data (land 
books, land certificates) are stored in electronic form which are then entered in the computerized land activities application (KKP). Overall in its implementation to prevent double certificates, this application is not fully maximized because there are still many land parcels that have been certified but have not been registered in the KKP application, so that there is still a possibility of overlapping certificates.

As for the factors that lead to a double certificate, it can be seen from 2 (two) factors. First, if seen from the community factor, there are still many people who do not fully control the boundaries of their land, usually people who have certificates have sold the land several times so that those who buy the land are the victims (dishonesty). It may also happen that the certificate owner intentionally or unintentionally points out the wrong boundaries. Second, if it is seen from the human resource factor of the Land Officedue to carelessness and carelessness of land officials in checking and researching the requested land.

\section{References}

Chandra, R. O. . (2020). Penyelesaian Sengketa Sertifikat Ganda Hak Atas Tanah Menurut PP No. 24/1997 tentang Pend aftaran Tanah. Jurnal Ilmiah Ilmu Hukum.

Negara Kesatuan Republik Indonesia. Undang-Undang Nomor 5 Tahun 1960 tentang Peraturan Dasar Pokok-pokok Agraria. , (1960).

Parmahan Sibuea, H. Y. (2011). Arti Penting Pendaftaran Tanah Untuk Pertama Kali. Negara Hukum, 2(2).

Razak, M., Patittingi, F., \& Maskun. (2020). Pemetaan Sertipikat Secara Digital (Plotting) dalam Memberikan Kepastian Hukum Terhadap Hak Atas Tanah. PETITUM, 8(2), 143-155.

Rizki, K. (2020). Perlindungan Hukum Pemegang Sertifikat Hak Milik Atas Terbitnya Sertifikat Ganda Berdasarkan Asas Kepastian Hukum. Aktualita (Jurnal Hukum).

Salam, S. (2017). Analisis Hukum Penetapan Tarif Pnbp Pada Pihak Tertentu Dalam Percepatan Sertifikasi Tanah. Justitia Jurnal Hukum, 1(1), 22.

Santoso, U. (2019). Pendaftaran dan Peralihan Hak Atas Tanah. Jakarta: Kencana.

Sumaya, P. (2018). Pemaknaan Tanah Swapraja dalam Konflik Pertanahan di Kota Cirebon. Al'Adl, 10(1).

Sutedi. (2008). Peralihan Hak Atas Tanah dan Pendaftarannya. Jakarta: Sinar Grafika. 